\title{
Density estimates of birds inhabiting fragments of cloud forest in southern Ecuador
}

\author{
MARK D. JACOBS and JON S. WALKER
}

\section{Summary}

Between June and September 1995 estimates were made of the population densities of birds inhabiting fragments of unprotected montane cloud forests in southern Ecuador. The study focused on 10 species: Bearded Guan Penelope barbata, Golden-plumed Parakeet Leptosittaca branickii, Red-faced Parrot Hapalopsittaca pyrrhops, White-capped Parrot Pionus seniloides, Grey-breasted Mountain-Toucan Andigena hypoglauca, Barred Fruiteater Pipreola arcuata, Turquoise Jay Cyanolyca turcosa, Great Thrush Turdus fuscater, Hooded Mountain-tanager Buthraupis montana, and Mountain Cacique Cacicus leucoramphus. Species assemblages and population densities varied greatly between sites, despite the presence of similar habitats and altitudinal ranges. Substantial populations of the threatened Bearded Guan, Grey-breasted Mountain-Toucan and Golden-plumed Parakeet were found in areas previously unstudied, as well as in areas previously known to be important. Currently unprotected areas are important for the conservation of montane cloud forest birds.

\section{Introduction}

Ecuador contains a great diversity of forest birds. It has also been noted to have the second highest rate of deforestation in Latin America (Simpson 1990). In the Ecuadorian high Andes virtually all forest habitats have been destroyed or at least disturbed by the effects of slash-and-burn agriculture (Bloch et al. 1991). Many valleys have been completely deforested (Terborgh and Winter 1983), leaving only small remnant forest fragments on the less accessible slopes. These tropical montane cloud forests (TMCF) are considered the most endangered habitat type within the country (Gentry 1986) and are similarly threatened on a global scale (Hamilton et al. 1994). In southern Ecuador the only large tracts of TMCF are the Podocarpus National Park at the border between the provinces of Loja and Zamora-Cinchipe (Bloch et al. 1991).

Little research has been carried out in the cloud-forest areas of southern Ecuador. Much recent work has focused on obtaining species lists, in order to "rapidly assess" large areas, and to define conservation priorities (Bloch et al. 1991. Best and Clarke 1991, Williams and Tobias 1994).

Studies of population densities of birds within unprotected TMCF fragments in southern Ecuador have been carried out in protected areas at Rió Mazan, in the province of Azuay (A. Gretton 1986, unpubl.), and a local conservation group, 
FUNDACION ARCOIRIS, has monitored populations in areas of TMCF within and surrounding the Podocarpus National Park. The focus of this study was on the four Red Data Book species listed below.

The Red-faced Parrot Hapalopsittaca pyrrhops is classified as an Endangered species endemic to Ecuador and northern Peru. It has been recorded at 12 localities in the Ecuadorian Provinces of Azuay, Loja and Morona-Santiago (Collar et al. 1994). These largely consist of unprotected and fragmented forests. Little was known about its biology (Forshaw 1989), until recent work focused on diet, behaviour, breeding biology (Toyne and Flanagan 1996, Toyne and Jeffcote 1994) and vocalizations (Toyne et al. 1995).

The Bearded Guan Penelope barbata is also endemic to Ecuador and northern Peru and is considered Vulnerable (Collar et al. 1994). Although sometimes found in high densities (Bloch et al. 1991), its numbers are thought to be on the decline (Collar et al. 1994) as a result of habitat loss.

The Golden-plumed Parakeet Leptosittaca branickii is classified as Vulnerable (Collar et al. 1994). It is widespread but only found in temperate Andean forests, with little known about its biology (Forshaw 1989).

The Grey-breasted Mountain-toucan Andigena hypoglauca is listed as Near Threatened (Collar et al. 1994), inhabits Ecuadorian temperate cloud forests, and is little known. Survival of this species is thought to be threatened by the ongoing destruction of the cloud forests (Bloch et al. 1991).

Several non-threatened species were also censused, including Barred Fruiteater Pipreola arcuata, Turquoise Jay Cyanolyca turcosa; Great Thrush Turdus fuscater, Hooded Mountain-Tanager Buthraupis montana, Mountain Cacique Cacicus leucoramphus and Scaly-naped Parrot Amazona mercenaria.

The purpose of this study was to produce density estimates and establish the status of birds inhabiting fragmented TMCF sites in southern Loja and to identify important sites for their conservation.

\section{Study areas and methods}

Between June 2 and September 12, 1995 three unprotected forest blocks were studied. Selva Alegre ( $\left.03^{\circ} 32^{\prime} \mathrm{S}, 79^{\circ} 22^{\prime} \mathrm{W}\right)$, is on the Saraguru-Manu road approximately $5 \mathrm{~km}$ from the small village of Selva Alegre. The 400-ha site is on the inter-Andean slopes and ranges in altitude from 2835 to $3130 \mathrm{~m}$. Surveyed habitats within the area included dwarf montane cloud forest (DMCF), montane cloud forest (MCF) and regenerating montane cloud forest (RMCF) (Toyne et al. 1995, Rasmussen et al. 1996). The principle threats to the area are felling, burning and grazing. These activities have produced a mosaic of cleared land and forest.

Chilla $\left(03^{\circ} 27^{\prime} \mathrm{S}, 79^{\circ} 38^{\prime} \mathrm{W}\right)$ is $2 \mathrm{~km}$ east from the small village of Chilla. The area of forest studied was estimated as 250 ha by pinpointing the outer boundaries from satellite photos, although it was noted that the site contained larger tracts of forest which were not studied. It is located on the Pacific slope of the Andes and ranges in altitude from 2200 to $2900 \mathrm{~m}$. Bird surveying was carried out in the largest of the three valleys present and included $\mathrm{MCF}$, transitional cloud forest/subtropical forest (TMCF/STF), and subtropical forest (STF). Large areas of undisturbed forest remained, although there was rapid clearance for grazing.

El Sauce $\left(03^{\circ} 45^{\prime} \mathrm{S}, 79^{\circ} 20^{\prime} \mathrm{W}\right)$, is $12 \mathrm{~km}$ north of Loja, $4 \mathrm{~km}$ from the town of 
Santiago. It is located along the Quebrada El Sauce on the inter-Andean slopes and ranges in altitude from 2835 to $3130 \mathrm{~m}$. Habitats surveyed consisted of MCF and RMCF and covered an area of approximately 250 ha, although the forest area is larger.

The variable circular plot (VCP) survey method proved to be the most appropriate form of distance sampling to estimate density in this study because vegetation structure limited ease of movement by the observer (Jones et al. 1995). Dense undergrowth restricted transect lines to established paths. Survey points were placed at intervals of 200 steps (approximately $150 \mathrm{~m}$ ) and marked for future reference. Each station was censused regularly.

Twenty-seven stations were set up in the Selva Alegre and were repeated an average of 11.7 times, 34 in Chilla with an average of 15.1 repeats, and 28 in El Sauce with an average of 18.4 repeats. In total 318 stations were censused in Selva Alegre, 515 in Chilla and 515 in El Sauce.

Censuses were carried out at o6hoo-11 hoo and 16 hoo-18hoo at times of peak bird activity. Censuses were not carried out in adverse weather conditions. Observers arriving at a station waited two minutes for the birds to settle down and then counted all birds for to minutes. The time of initial contact, distance from observer, group size, and whether seen or heard only was recorded for each encounter. Before fieldwork all observers practised distance estimation and became familiar with the study species (Kepler and Scott 1981).

Data were analysed using the DISTANCE program (Laake et al. 1994). Areas of forest blocks were estimated from satellite maps and used to calculate minimum and maximum population sizes utilizing the $95 \%$ confidence limits obtained from the density estimates. Information on average and maximum flock sizes were estimated using all visual sightings (both the unit effort and VCP).

\section{Results}

Auditory contacts accounted for $96.5 \%$ of total contacts at VCP stations. Detection curves for auditory and visual contacts differed sufficiently to distort the process of model fitting by DISTANCE. Density estimates are therefore based exclusively on auditory contacts because sample sizes of visual contacts were found to be too small to obtain precise results. Contacts with flying birds were not used in analysis to minimize the possibilities of double counting highly mobile species (Jones et al. 1995).

Both the species assemblage and the densities of these species were found to vary greatly between sites (Tables 1-3), despite the presence of similar habitats and altitudinal ranges. The Bearded Guan was present at all three sites at varying densities. The Red-faced Parrot was not recorded in Chilla but was seen in relatively high densities at Selva Alegre, in comparison to El Sauce. The Goldenplumed Parakeet was not contacted in Selva Alegre and was found at low densities in both Chilla and El Sauce. The Grey-breasted Mountain-toucan was found in all of the study sites. The Mountain Cacique was not present at Chilla and was found to be at highest densities in Selva Alegre. The White-capped Parrot was present in all sites, with highest densities in Selva Alegre. The Barred Fruiteater was not found at Chilla, and was estimated to be at similar densities in both Selva Alegre and El Sauce. The Turquoise Jay was found in all sites with 
Table 1. Flock size information and estimation of densities of bird populations in Selva Alegre

\begin{tabular}{|c|c|c|c|c|c|c|c|}
\hline Bird species & $\begin{array}{l}\text { Mean } \\
\text { flock } \\
\text { size }\end{array}$ & $\begin{array}{l}\text { Maximum } \\
\text { flock size }\end{array}$ & $\begin{array}{l}\text { Sample size } \\
\text { (no. of } \\
\text { contacts) }\end{array}$ & $\begin{array}{l}\text { Density } \\
\text { estimate } \\
\mathrm{km}^{-2}\end{array}$ & $\begin{array}{l}95 \% \\
\text { Confidence } \\
\text { intervals }\end{array}$ & $\begin{array}{l}\text { Minimum } \\
\text { population } \\
\text { estimate }\end{array}$ & $\begin{array}{c}\text { Maximum } \\
\text { population } \\
\text { estimate }\end{array}$ \\
\hline $\begin{array}{l}\text { Turquoise Jay } \\
\text { Cyanolyca turcosa }\end{array}$ & 2.0 & 10 & 289 & 137.4 & $113.6-166.2$ & 454 & 665 \\
\hline $\begin{array}{l}\text { Red-faced Parrot } \\
\text { Hapalopsittaca } \\
\text { pyrrhops }\end{array}$ & 4.5 & 20 & 55 & 88.0 & $42.3^{-183.4}$ & 169 & 734 \\
\hline $\begin{array}{l}\text { Mountain Cacique } \\
\text { Cacicus } \\
\text { leucoramphus }\end{array}$ & 2.1 & 10 & 206 & 57.4 & $42.6-77 \cdot 3$ & 171 & 309 \\
\hline $\begin{array}{l}\text { White-capped } \\
\text { Parrot } \\
\text { Pionus seniloides }\end{array}$ & $7 \cdot 7$ & 11 & 16 & 57.1 & $16.8-193.3$ & 67 & 773 \\
\hline $\begin{array}{l}\text { Great Thrush } \\
\text { Turdus fuscater }\end{array}$ & 1.3 & 3 & 49 & 29.7 & $20.9-42.1$ & 83 & 169 \\
\hline $\begin{array}{l}\text { Bearded Guan } \\
\text { Penelope barbata }\end{array}$ & 1.4 & 3 & 52 & 17.1 & $10.4^{-27.9}$ & $4^{2}$ & 112 \\
\hline $\begin{array}{l}\text { Grey-breasted } \\
\text { Mountain-Toucan } \\
\text { Andigena } \\
\text { hypoglauca }\end{array}$ & 1.1 & 3 & 62 & 16.5 & $9.7^{-28.1}$ & 39 & 112 \\
\hline $\begin{array}{l}\text { Barred Fruiteater } \\
\text { Pipreola arcuata }\end{array}$ & 1.8 & 2 & 15 & 15.9 & $7.8-32.2$ & 31 & 129 \\
\hline
\end{tabular}

Table 2. Flock size information and estimation of densities of bird populations in Chilla

\begin{tabular}{|c|c|c|c|c|c|c|c|}
\hline Bird species & $\begin{array}{c}\text { Mean } \\
\text { flock } \\
\text { size }\end{array}$ & $\begin{array}{l}\text { Maximum } \\
\text { flock size }\end{array}$ & $\begin{array}{c}\text { Sample size } \\
\text { (no. of } \\
\text { contacts) }\end{array}$ & $\begin{array}{c}\text { Density } \\
\text { estimate } \\
\mathrm{km}^{-2}\end{array}$ & $\begin{array}{c}95 \% \\
\text { Confidence } \\
\text { intervals }\end{array}$ & $\begin{array}{l}\text { Minimum } \\
\text { population } \\
\text { estimate }\end{array}$ & $\begin{array}{c}\text { Maximum } \\
\text { population } \\
\text { estimate }\end{array}$ \\
\hline Great Thrush & 1.8 & 2 & 172 & 68.5 & $50.0-93.9$ & 125 & 235 \\
\hline Turquoise Jay & 1.6 & 6 & 274 & 62.5 & $48.5-80.7$ & 121 & 202 \\
\hline $\begin{array}{l}\text { Grey-breasted } \\
\text { Mountain-Toucan }\end{array}$ & 1.5 & 2 & 35 & 3.9 & $2.4-6.3$ & 6 & 16 \\
\hline Bearded Guan & 1.8 & 3 & 37 & 2.3 & $1.4-3.7$ & 3 & 9 \\
\hline $\begin{array}{l}\text { Golden-plumed } \\
\text { Parakeet } \\
\text { Leptosittaca } \\
\text { branickii }\end{array}$ & $15 \cdot 3$ & 27 & 37 & 2.3 & $1.4-3.7$ & 3 & 9 \\
\hline $\begin{array}{l}\text { Red-billed Parrot } \\
\text { Pionus sordidus }\end{array}$ & 1.8 & 4 & 17 & 1.1 & $0.6-2.0$ & 2 & 5 \\
\hline $\begin{array}{l}\text { White-capped } \\
\text { Parrot }\end{array}$ & 3.0 & 4 & 15 & 0.7 & $0.3-1.9$ & 1 & 5 \\
\hline
\end{tabular}

the highest density recorded at Selva Alegre. The Great Thrush was found to have the highest density in El Sauce.

The Scaly-naped Parrot was noted at both El Sauce and Chilla but numbers were too low to produce an estimate in the latter area. The Hooded Mountaintanager was found in both Selva Alegre and El Sauce but the data set was too small for Selva Alegre to produce a density estimate. Average flock sizes were found to be similar between sites for all species but the White-capped Parrot. 
Table 3. Flock size information and estimation of densities of bird populations in El Sauce

\begin{tabular}{|c|c|c|c|c|c|c|c|}
\hline Bird species & $\begin{array}{l}\text { Mean } \\
\text { flock } \\
\text { size }\end{array}$ & $\begin{array}{c}\text { Maximum } \\
\text { flock size }\end{array}$ & $\begin{array}{l}\text { Sample size } \\
\text { (no. of } \\
\text { contacts) }\end{array}$ & $\begin{array}{c}\text { Density } \\
\text { estimate } \\
\mathrm{km}^{-2}\end{array}$ & $\begin{array}{c}95 \% \\
\text { Confidence } \\
\text { intervals }\end{array}$ & $\begin{array}{c}\text { Minimum } \\
\text { population } \\
\text { estimate }\end{array}$ & $\begin{array}{c}\text { Maximum } \\
\text { population } \\
\text { estimate }\end{array}$ \\
\hline Great Thrush & 1.7 & 9 & 194 & 168.9 & $109.7^{-260.1}$ & 274.2 & 650.2 \\
\hline Turquoise Jay & 2.4 & 6 & 345 & 57.0 & $45.8-70.9$ & 114.6 & 177.3 \\
\hline $\begin{array}{l}\text { Hooded } \\
\text { Mountaintanager }\end{array}$ & 2.1 & 6 & 43 & 47.9 & $20.0-114.2$ & 50.1 & 285.5 \\
\hline $\begin{array}{l}\text { Buthraupis } \\
\text { montana }\end{array}$ & & & & & & & \\
\hline Red-faced Parrot & 5.3 & 19 & 32 & 25.3 & $10.6-60.4$ & 26.5 & 151.0 \\
\hline Barred Fruiteater & 1.0 & 1 & 36 & 23.0 & $12.6-42.2$ & 31.4 & 105.5 \\
\hline Mountain Cacique & 3.4 & 8 & 144 & 17.8 & $13.9-22.6$ & 34.8 & 56.6 \\
\hline Bearded Guan & 1.3 & 2 & 57 & 6.7 & $4.5-10.1$ & 11.1 & 25.3 \\
\hline $\begin{array}{l}\text { Golden-plumed } \\
\text { Parakeet }\end{array}$ & 13.5 & 22 & 30 & 6.6 & $2.9-15.1$ & 7.2 & 37.8 \\
\hline $\begin{array}{l}\text { White-capped } \\
\text { Parrot }\end{array}$ & 3.4 & 5 & 24 & 5.6 & $2.9-10.9$ & $7 \cdot 3$ & 27.2 \\
\hline $\begin{array}{l}\text { Scaly-naped } \\
\text { Amazon } \\
\text { Amazona } \\
\text { mercenaria }\end{array}$ & 4.0 & 7 & 27 & 2.3 & $1.1-4.8$ & 2.8 & 12.0 \\
\hline $\begin{array}{l}\text { Grey-breasted } \\
\text { Mountain-Toucan }\end{array}$ & 1.0 & 1 & 31 & 1.5 & $0.9-2.5$ & 2.3 & 6.2 \\
\hline
\end{tabular}

\section{Discussion}

The sparse literature available on the four Red Data Book species (Bearded Guan, Red-faced Parrot, Golden-plumed Parakeet and Grey-breasted Mountain-toucan) indicates that clearing of cloud forest for grazing and agriculture is a major threat to their existence. Habitat destruction was observed at all three study sites. The density estimates show that all three sites provide a stronghold for at least three of the four Red Data Book species and are therefore of major conservation importance.

Selva Alegre should be protected because it contains particularly high numbers of the endangered endemic Red-faced Parrot (169-734 individuals) and significant numbers of Bearded Guan (42-112 individuals) and Grey-breasted MountainToucan (39-113 individuals). Selva Alegre would provide a particularly good area for ornithological ecotourism because the area is accessible and contains many species of interest that are easily seen as a result of the mosaic of open fields and forest. Our results indicate that the highest densities of birds, with the exception of Great Thrush are found here.

El Sauce is also an important area because of the population of the Goldenplumed Parakeet ( $7-38$ individuals). Protection is recommended and, as with Selva Alegra, there is potential for ecotourism. The site is also of special interest as the area of continuous forest is much larger than that surveyed in this study. The forest also exists in close proximity to other forest blocks of varying altitude. These two factors increase the importance of the area for species conservation as larger populations of both the endangered study species and others of interest may be present. The existence of larger areas of forest may also increase viability 
of endangered populations such as the Golden-plumed Parakeet contained within the study area.

Chilla is of particular interest because it is a rare example of a Pacific-facing cloud forest. Its avifauna has not previously been described. Numbers of Bearded Guan (11-25 individuals) and Golden-plumed Parakeet (4-9 individuals) were found. The surveyed area represents only part of the forest, being connected with STF on the lower slopes, which could provide suitable habitat for larger populations of threatened species of birds.

A maximum flock size of 27 Golden-plumed Parakeet was noted from visual records in Chilla forest but the population was estimated at a maximum of nine individuals, this discrepancy being explained by the species's nomadic behaviour (Forshaw 1989). They were absent from the site for over one third of fieldwork, presumably to forage in other suitable areas outside the census area. This nomadic behaviour may have great implications for future conservation of this and similar species as a network of forest fragments may be needed to support a viable population.

The density estimates obtained for the Red Data Book species emphasize the importance of these sites and show that unprotected TMCF fragments in south Ecuador contain substantial populations of threatened birds. The study also highlights the importance of conserving networks of fragments in order to support wider ranging nomadic species such as Golden-plumed Parakeet. The protection of the sites studied and others like them could ensure the future existence of the Red Data Book species studied in the face of widespread habitat destruction.

\section{Acknowledgements}

We thank Mark Jeffcote for his invaluable help in planning the expedition and all at FUNDACION ARCOIRIS, especially Eduardo and Rodrigo Tapia, for help, support and advice. Sarah Huchison and INEFAN provided much assistance. We thank Jeremy Flanigan, Fabian Rodas, Pablo Quieba and Pablo Laronzo for invaluable help with fieldwork. We also thank Martin Jones, Gillian Key, Stuart Marsden, Barry Stevens-Wood and Paul Toyne for help in the planning of the expedition. For their financial support we thank Billesdon Parish Church, The Russel and Mary Foreman 1980 Charitable Trust, The Albert Reckitt Charitable Trust, The Royal Geographical Society, Oadby Rotary Club, RTZ Ltd and The Walter Guinness Charitable Trust. Stuart Marsden and Paul Thacker kindly commented on the manuscript.

\section{References}

Best, B.J. and Clarke, C.T. eds. (1991) The threatened birds of Sozoranga region, southwest Ecuador. ICBP, Study Report No. 44. Cambridge UK.

Bloch, H., Poulsen, M.K., Rahbek, C. and Rasmussen, J.F. (1991) A survey of the montane forest avifauna of the Loja Province, southern Ecuador. ICBP, Study Report No. 49. Cambridge UK.

Collar, N. J., Crosby, M. J. and Strattersfield, A. J. (1994) Birds to watch 2: the world list of threatened birds. Cambridge, U.K.: BirdLife International (BirdLife Conservation Series 4).

Forshaw, J. M. (1989) Parrots of the World. Pode, U.K.: Blandford Press.

Gentry, A. H. (1986) Endemism in tropical verses temperate plant communities. Pp. 153- 
181 in M. E. Soule, ed. Conservation biology: the science of scarcity and diversity. Sunderland, Mass.: Sinauer.

Hamilton, L. S., James, O. J. and Scatena, F. N. (1984) The Puerto Rico tropical cloud forest symposium: introduction and workshop synthesis. In L. S. Hamilton, J. O. Jurik and F. N. Scatena, eds. Tropical montane cloud forest. New York: Springer-Verlag.

Jones, M. J., Linsley, M. D. and Marsden, S. J. (1995) Population sizes, status and habitat associations of the restricted-range bird species of Sumba, Indonesia. Bird Conserv. Internatn 5:21-52.

Kepler, C. B. and Scott, J. M. (1981) Reducing bird count variability by training observers. Stud. Avian Biol. 6:366-371.

Laake, J. L., Buckland, S. T., Anderson, D. R. and Burnham, K. P. (1994). Distance users' guide, version 2.1. Fort Collins, Colo.: Colorado Co-operative Fish and Wildlife Research Unit, Colorado State University.

Rasmussen, J. F., Rahbek, C., Poulsen, B. O., Poulsen, M. K. and Bloch, H. (1996) Distribution records and natural history notes on threatened and little-known birds of southern Ecuador. Bull. Brit. Orn. Club 116:26-46.

Simpson, S. (1990) The Times guide to the environment. London: Times Books.

Terborgh, J. and Winter, B. (1983) A method for sighting parks and reserves with special reference to Colombia and Ecuador. Biol. Conserv. 27:45-58.

Toyne, E. P. and Flanagan, J. N. M. (1996) First nest record of Red-faced Parrot Hapalopsittaca pyrrhops. Cotinga 5:43-45.

Toyne, E. P. and Jeffcote, M. T. (1994) Nesting records of Pionus species in southern Ecuador. Bull. Brit. Orn. Club.114:124-127.

Toyne, E. P., Flanagan, J. N. M. and Jeffcote, M. T. (1995) Vocalisation of the endangered Red-faced Parrot Hapalopsittaca pyrrhops in southern Ecuador. Orn. Neotrop. 6:125-128.

Williams, R.S.R. and Tobias, J.A. (1994) The conservation of southern Ecuador's threatened avifauna. Final report of the Amaluza project, 1990-1991. Birdlife International Study Report No. 6o. Cambridge UK.

MARK D. JACOBS and JON S. WALKER

Department of Biological Sciences, Manchester Metropolitan University, Oxford Road, Manches$\operatorname{ter} M_{1}{ }_{5} G D, U . K$. 